\title{
A STUDY OF THE RELATIONSHIP BETWEEN RADIOACTIVE SODIUM CLEARANCE AND DIRECTLY MEASURED BLOOD FLOW IN THE BICEPS MUSCLE OF THE DOG
}

\author{
BY THEODORE C. PRENTICE, ROBERT R. STAHL, NORMAN A. DIAL, AND \\ FRANK V. PONTERIO \\ (From the Division of Surgery, Army Medical Service Graduate School, Walter Reed Army \\ Medical Center, Washington, D. C.)
}

(Submitted for publication October 18, 1954; accepted December 8, 1954)

Since the introduction by Kety in 1949 (1) of the radioactive sodium clearance method for measuring regional blood flow in muscle, much work using this method has been published. The results have been varied, and conflicting in many respects. Some have supported the contention that the rate of sodium clearance is a good index of local muscle blood flow $(2,3)$, others have not $(4,5)$. Perhaps the dominant conclusions one draws from existing data are that: 1) There is a wide range of values for sodium clearance rate from muscle in the resting human; 2) there is a large overlap between clearance rates from a normal group and from a group with known peripheral vascular disease; and 3) nevertheless for any given individual those influences such as exercise, drugs, and temperature, which have been noted to increase or decrease muscle blood flow, usually cause parallel changes in the rate of sodium clearance from muscle.

The problem arises then as to whether the wide range of clearance values noted in normals, and the considerable overlap found between normal and pathologic material, reflect actual variation in regional flow rates or are due to inherent errors in the clearance method as an index of flow.

To further elucidate this problem and to test as rigorously as possible the accuracy and dependability of the sodium clearance method as a measurement of total blood flow, a series of direct and simultaneous comparisons between total blood flow through muscle and sodium clearance therefrom was carried out.

Any conclusions concerning blood flow as related to radioactive sodium clearance from this study must of necessity refer to total blood flow since that was the quantity measured. Effective blood flow, which refers to the fraction of total blood flow going through the capillaries, cannot be directly measured at the present time. Therefore any conclusions relating the clearance rate of radioactive sodium to effective blood flow (capillary circulation) are in the realm of speculation.

\section{METHODS}

Ten experiments were performed to determine the relationship between the crearance rate of radioactive sodium from an injected intramuscular site and the blood flow through the muscle. Dogs used in this experiment, ranging in weight from 12.7 to $23 \mathrm{Kg}$., were anesthetized with Sodium Nembutal.

A large incision was made in the skin of the foreleg extending from the anterior superior surface of the shoulder joint, distally and somewhat medially, to the elbow joint. The skin and subcutaneous tissue were reflected and the underlying muscle was exposed. Several large muscles, serratus ventralis, brachiocephalicus, pectoralis superficialis, and pectoralis profundus, were divided and reflected so as to expose the biceps muscle. This also allowed for exposure of the brachial artery and vein which were about one centimeter medially and along the longitudinal axis of the muscle. The brachial artery and vein and their branches and tributaries were carefully dissected and freed of their connective tissue attachments. In most of the animals three pairs of nutrient vessels supplied the biceps muscle (Figure 1). The artery and vein which entered the middle portion of the muscle on its medial aspect were the largest in caliber and these vessels were the ones used for perfusion. The smaller pairs of vessels at the proximal and distal portions of the muscle were ligated. All other branches of the brachial artery and tributaries of the brachial vein were ligated and divided. A cannula $\left(C_{\nabla}\right)$ was placed in the brachial vein and this vein was ligated just distal to the point where the vein from the biceps muscle joined it. This made possible the collection of the venous outflow from the biceps muscle. The experimental dogs received heparin approximately 


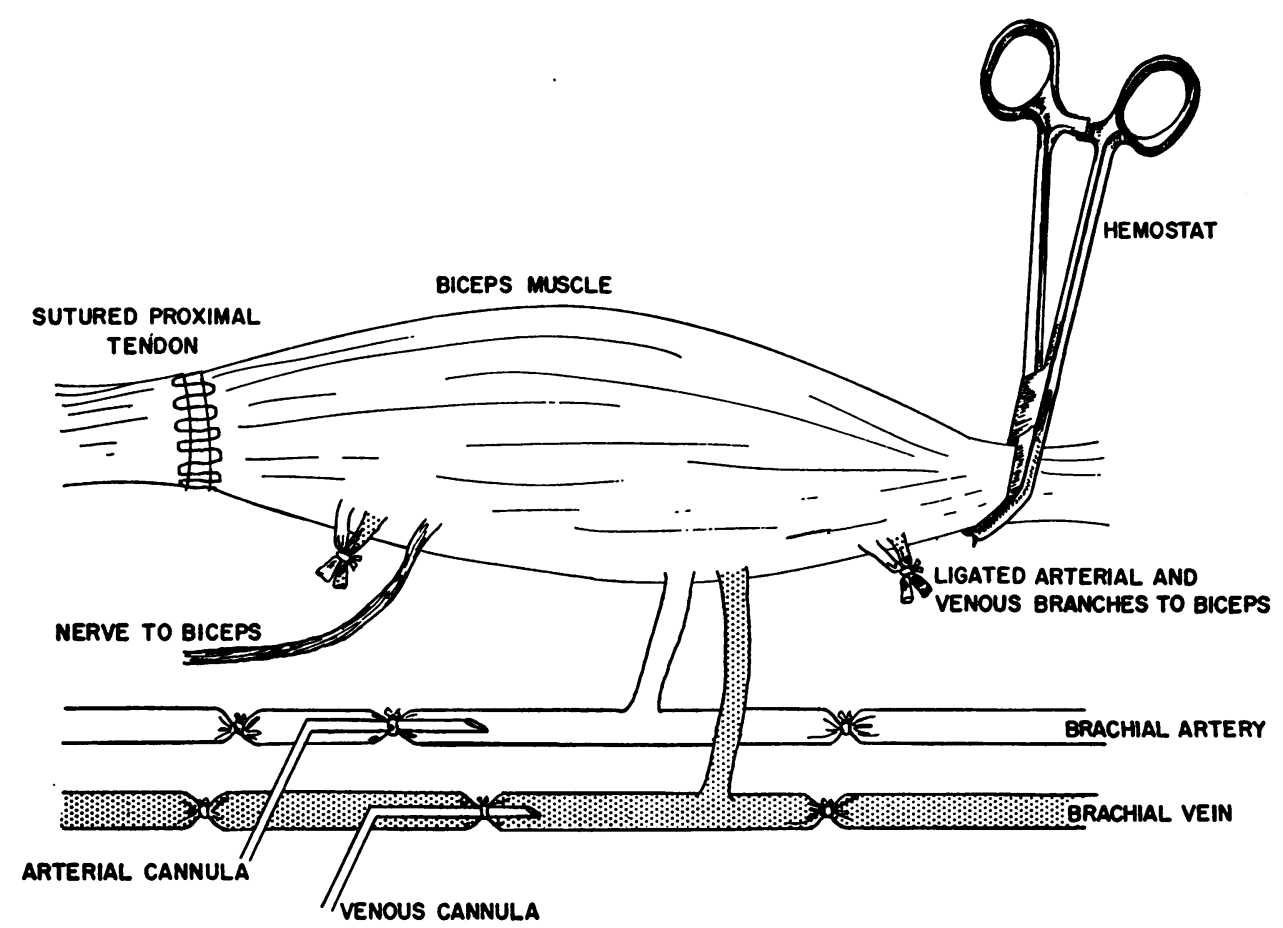

Fig. 1. Schematic Diagram of Local Anatomy and Dissection

$4.5 \mathrm{mg}$. per $\mathrm{Kg}$. of body weight just prior to the insertion of the venous cannula. A cannula $\left(C_{\Delta}\right)$ was placed in the brachial artery which was ligated just distal to the arterial branch to the biceps. The arterial cannula was then connected to the perfusion pump with Tygon tubing.

In each experiment the venous outflow from the biceps muscle was measured immediately after cannulation of the brachial vein and just prior to the cannulation of the brachial artery. In all instances a relatively large rate of flow was found. These values, however, were not reported since they did not appear directly relevant to the experiment and ligation of numerous branches of the brachial artery would tend to divert more blood to the biceps muscle.

The nerve supply to the biceps was left intact except in Experiment No. 2 when it was inadvertently severed during dissection.

Both the tendon of origin and tendon of insertion of the biceps muscle were severed. This was necessary so as to obliterate any blood supply reaching the muscle by way of the tendons. At this point in the dissection the entire muscle could be lifted and completely separated from the extremity except for the arterial branch, venous tributary, and the nerve supplying the biceps. The proximal tendon, the tendon of origin, was sutured together again. The more distal tendon, the tendon of insertion, was short; the tendinous portion of the muscle was clamped with a small hemostat. The hemostat was anchored to the extremity with thread so as to maintain anatomic relations and relative muscle stretch.
Donor dogs were anesthetized, heparinized (approximately $4.5 \mathrm{mg}$. per $\mathrm{Kg}$. of heparin), and bled into an open reservoir. In all but Experiment Nos. 1, 3, and 4 this blood was passed through an oxygenating device. The oxygenating device for the blood consisted of a Vigreaux distillation column to which a glass joint and side tube was attached near the bottom. Oxygen was allowed to enter through this side tube. Blood was poured into the column at the top and bubbles of oxygen passed up through the tube as the column of blood descended. This method of oxygenation resulted in very little hemolysis as demonstrated by the plasma hemoglobin values before and after passage through the oxygenating column. Prior to this passage of the blood through the column, 5 to $10 \mathrm{ml}$. of heparin was added. This blood was then placed in two open reservoirs A and B (Figure 2).

A Phipps and Bird Infusion Pump was utilized to establish a relatively constant blood flow through the muscle (Figure 2). This pump pushes a standard $50 \mathrm{ml}$. hypodermic syringe at an adjustable constant speed. Thus a steady flow of blood to the biceps muscle could be maintained for a desired period of time. The syringe (S) was filled with blood from reservoir A by changing the position of the stopcock at $D$. While the syringe was being filled, flow to the isolated muscle could be maintained by gravity from reservoir B by changing position of Stopcock E.

Pressure within the system was recorded with a Statham Pressure Transducer, Model P23A (c), which was placed into the perfusion circuit through a $T$-tube at F. The pressure was recorded through a Grass Bridge 
Amplifier on a direct-writing ink oscillograph. Mean pressures were obtained by planimetric integration.

Temperature of the room was recorded continuously on a Brown Recording Thermograph.

Blood samples for analysis of hemoglobin and per cent $\mathrm{O}_{2}$ saturation were obtained just proximal to the arterial cannula through the three-way stopcock at $\mathrm{G}$.

Radioactive sodium, $\mathrm{Na}^{2}, 5$ microcuries in $0.1 \mathrm{ml}$. isotonic $\mathrm{NaCl}$, was injected approximately one centimeter into the biceps muscle through a No. 26 gauge needle. Occasionally a small reflux of the injected material would appear at the injection site after the withdrawal of the needle. This was removed with gauze moistened with saline and the surface then blotted with dry gauze.

A lead-shielded Nuclear Scintillation Counter, Model No. DS1 and a Nuclear Scaler, Model No. 165, were used to follow the disappearance rate of the radioactive sodium from the muscle. The scintillation assembly was placed over the injection site one inch from the surface of the muscle. No additional shielding of the aperture of the scintillation tube was used to eliminate beta radiation. (Previously at this distance there was no difference in counting rate between samples counted with an aluminum absorber adequate to eliminate beta radiation and those counted without the aluminum absorber.) Sufficient sample and background counts were measured to assure a standard deviation of \pm 2 per cent or less for all but the weakest samples. Rarely, late in an experiment, the one minute counting rate had fallen to a level producing a standard deviation of \pm 5 per cent.

After injection of the $\mathrm{Na}^{\mathrm{a}}$ and placement of the scintillation counter repeated one-minute counts were recorded with fifteen-second intervals between each count. Usually eight successive counts were recorded and the interval of time over which these counts were taken constituted a clearance period. Occasionally as few as five or as many as nine counts were used, depending upon the reproducibility of the volumes of the two-minute collections of venous blood during the clearance period.

Blood flow through the biceps muscle was measured by collecting the venous outflow from the biceps muscle through a cannula in the brachial vein. During all clearance periods the venous blood was collected for twominute intervals in 10 milliliter volumetric mixing cylinders. Thus the sum of these two-minute volumes was determined during the total time required for a clearance period. The mean venous outflow was then calculated in milliliters per minute. Later when the weight of the biceps muscle was determined, the mean venous outflow was expressed in milliliters per minute per 100 grams of muscle. The sum of the volumes of blood collected for two-minute intervals during a clearance period was determined and the mean flow per two-minute interval was calculated for the entire clearance period. All clearance periods which contained two-minute volumes of blood which deviated more than ten per cent from the mean for that period were discarded. This was taken as evidence of an inconstant flow during the clearance period.

The biceps muscle preparation in this experiment had a completely isolated circulation. Fresh donor dog's blood was infused into the muscular arterial branch supplying the muscle and the total venous outflow from the muscle was collected and discarded. Consequently, in

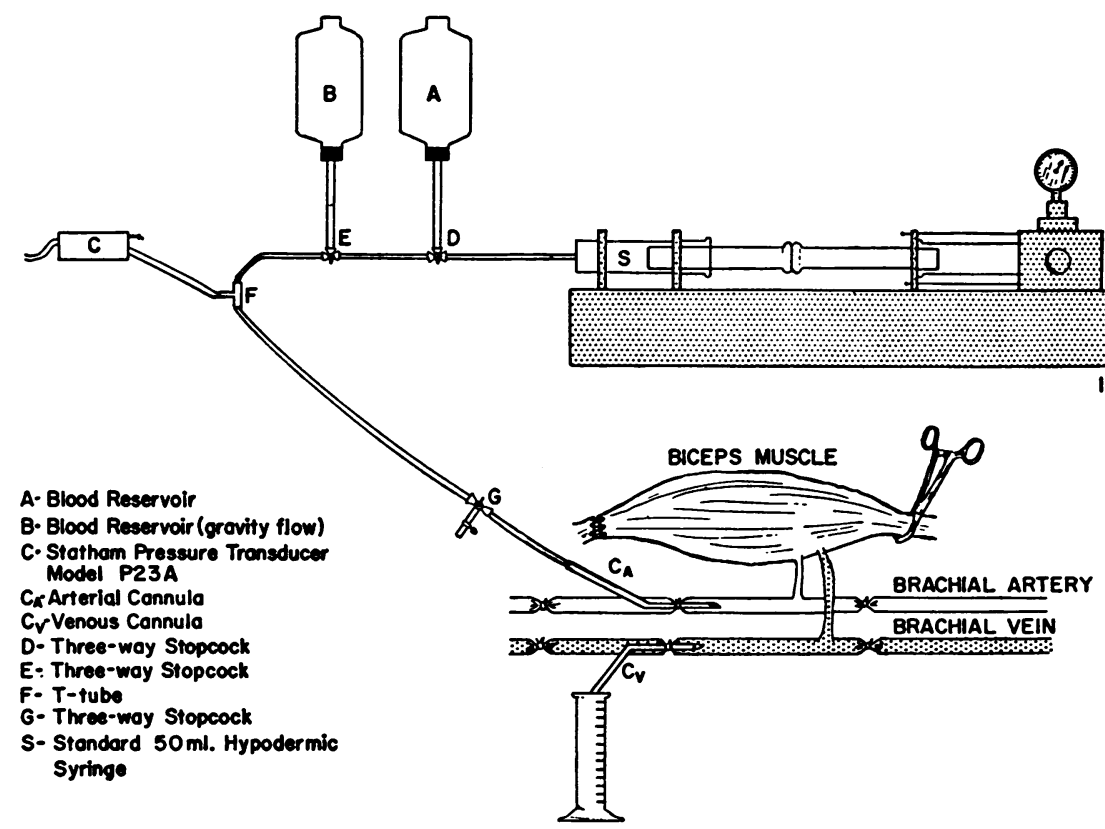

Fig. 2. Schematic Diagram Showing Perfusion Apparatus and Its Relationship to Perfused Muscle 
TABLE I

Summary of the data from the experiments where $\mathrm{Na}$ was injected intramuscularly-Each horizontal row of figures in a given experiment refers to the data obtained during one clearance period in that experiment

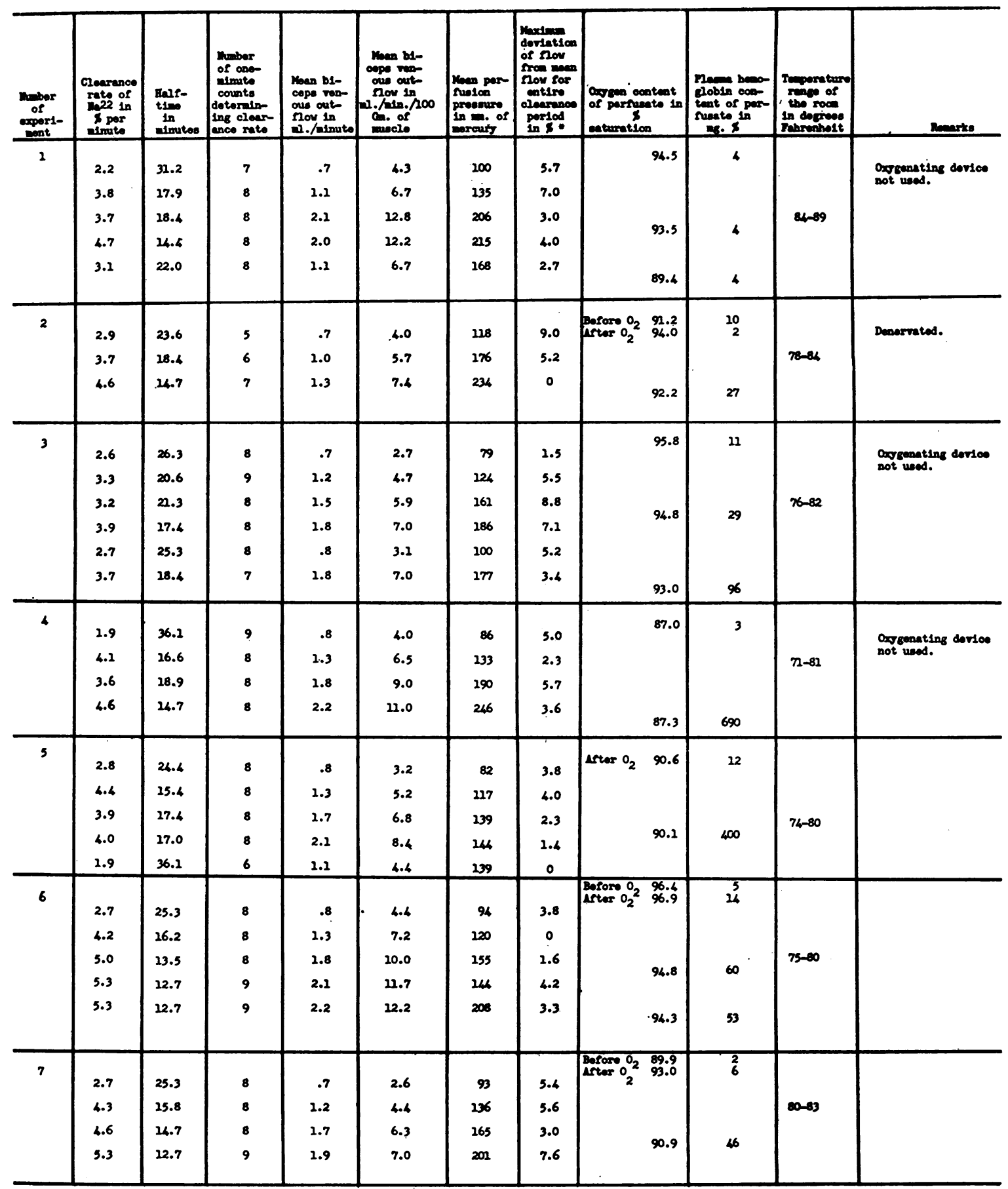

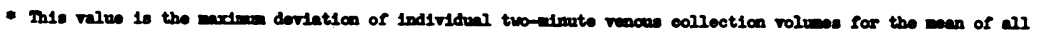
two-dnuto collection roluese for the entire clearanoe perlod, expresed in per cont. 
TABLE I-Continued

\begin{tabular}{|c|c|c|c|c|c|c|c|c|c|c|c|}
\hline $\begin{array}{l}\text { the ber } \\
\text { of } \\
\text { copert- } \\
\text { rent }\end{array}$ & 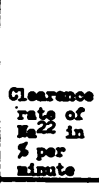 & $\begin{array}{l}\text { Ene- } \\
\text { tin: } \\
\text { in } \\
\text { einutes }\end{array}$ & 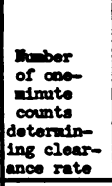 & 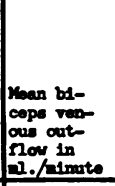 & 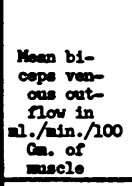 & $\begin{array}{l}\text { Noen per- } \\
\text { rusion } \\
\text { proseure } \\
\text { in . of. of } \\
\text { mercury }\end{array}$ & $\begin{array}{l}\text { laxdian } \\
\text { deorlation } \\
\text { of now } \\
\text { from woen } \\
\text { now for } \\
\text { entire } \\
\text { clearance } \\
\text { porlod } \\
\text { in } 8 \text {. }\end{array}$ & $\begin{array}{l}\text { orggen content } \\
\text { of perfusato in } \\
8 \\
\text { saturation }\end{array}$ & $\begin{array}{l}\text { Plase homo- } \\
\text { globin con- } \\
\text { tent of por- } \\
\text { rueato in } \\
\text { eq. } 8\end{array}$ & $\begin{array}{l}\text { Tenperature } \\
\text { range of } \\
\text { the roce } \\
\text { In degrees } \\
\text { Prehrenhelt }\end{array}$ & Bunitse \\
\hline 8 & $\begin{array}{l}3.3 \\
4.9 \\
6.5 \\
6.4\end{array}$ & $\begin{array}{l}20.6 \\
23.8 \\
20.3 \\
20.5\end{array}$ & $\begin{array}{l}8 \\
8 \\
8 \\
8\end{array}$ & $\begin{array}{l}.8 \\
1.3 \\
1.7 \\
2.0\end{array}$ & $\begin{array}{l}2.6 \\
4.2 \\
5.5 \\
6.5\end{array}$ & $\begin{array}{r}54 \\
85 \\
216 \\
237\end{array}$ & $\begin{array}{l}3.8 \\
9.3 \\
4.6 \\
8.3\end{array}$ & $\begin{array}{r}\text { Before } 0_{2} 94.5 \\
\text { After } 0_{2} \\
\\
\\
96.5\end{array}$ & $\begin{array}{l}2 \\
5 \\
51\end{array}$ & $72-77$ & \\
\hline 9 & $\begin{array}{l}2.1 \\
3.2 \\
4.6 \\
5.4\end{array}$ & $\begin{array}{l}32.7 \\
22.0 \\
24.7 \\
12.5\end{array}$ & $\begin{array}{l}8 \\
8 \\
8 \\
7\end{array}$ & $\begin{array}{l}.8 \\
1.2 \\
1.6 \\
2.1\end{array}$ & $\begin{array}{l}3.5 \\
5.2 \\
7.0 \\
9.1\end{array}$ & $\begin{array}{r}93 \\
230 \\
186 \\
157\end{array}$ & $\begin{array}{l}6.6 \\
2.4 \\
1.8 \\
6.7\end{array}$ & $\begin{array}{r}\text { Before } 0_{2} 89.1 \\
\text { After } 0_{2} \\
\\
94.8 \\
95.3\end{array}$ & $\begin{array}{r}9 \\
22 \\
192\end{array}$ & $75-79$ & \\
\hline 20 & $\begin{array}{l}3.7 \\
3.7 \\
4.6 \\
3.5 \\
4.1 \\
3.6\end{array}$ & $\begin{array}{l}28.4 \\
18.4 \\
14.7 \\
19.5 \\
16.6 \\
18.9\end{array}$ & $\begin{array}{l}9 \\
7 \\
9 \\
9 \\
7 \\
7\end{array}$ & $\begin{array}{l}1.5 \\
2.6 \\
1.8 \\
2.6 \\
1.8 \\
1.6\end{array}$ & $\begin{array}{l}5.6 \\
5.2 \\
6.7 \\
5.9 \\
6.7 \\
5.9\end{array}$ & $\begin{array}{r}105 \\
117 \\
93 \\
146 \\
89 \\
7\end{array}$ & $\begin{array}{l}9.6 \\
4.8 \\
5.5 \\
4.2 \\
7.9 \\
1.8\end{array}$ & $\begin{array}{r}\text { Before } 0_{2} 81.0 \\
\text { ifter } 0_{2}^{2} \\
88.8 \\
89.9 \\
\\
\\
86.8 \\
\\
85.2\end{array}$ & $\begin{array}{r}4 \\
23 \\
660 \\
420 \\
222\end{array}$ & $74-79$ & \\
\hline & & & IsC & arac $\Delta$ M & IIC rascts & & & & & · & \\
\hline $\boldsymbol{u}$ & $\begin{array}{l}2.6 \\
3.7 \\
4.5 \\
6.2\end{array}$ & $\begin{array}{l}26.3 \\
18.4 \\
25.1 \\
10.8\end{array}$ & $\begin{array}{l}8 \\
8 \\
8 \\
8\end{array}$ & $\begin{array}{l}.8 \\
1: 6 \\
1.8 \\
2.2\end{array}$ & $\begin{array}{l}2.6 \\
4.5 \\
5.8 \\
7.1\end{array}$ & $\begin{array}{l}56 \\
59 \\
98 \\
93\end{array}$ & $\begin{array}{l}5.0 \\
2.1 \\
4.3 \\
3.1\end{array}$ & $\begin{array}{rr}\text { Before } 0_{2} & 84.4 \\
\text { After } 0_{2} & 94.8 \\
& \\
& 90.4\end{array}$ & $\begin{array}{r}6 \\
45 \\
425\end{array}$ & $73-79$. & 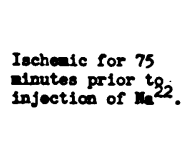 \\
\hline 21 & $\begin{array}{l}1.5 \\
3.8 \\
5.2\end{array}$ & $\begin{array}{l}45.9 \\
17.9 \\
23.0\end{array}$ & $\begin{array}{r}10 \\
8 \\
9\end{array}$ & $\begin{array}{l}.8 \\
1.3 \\
1.6\end{array}$ & $\begin{array}{l}2.9 \\
4.5 \\
5.7\end{array}$ & $\begin{array}{r}59 \\
75 \\
214\end{array}$ & $\begin{array}{l}6.9 \\
3.1 \\
6.2\end{array}$ & 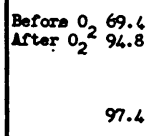 & 213 & $73-80$ & $\begin{array}{l}\text { Ischenic for } 75 \\
\text { nimutes prior to } \\
\text { Injection of } 1 a^{22} .\end{array}$ \\
\hline 30 & $\begin{array}{r}.1 .4 \\
2.5 \\
3.5\end{array}$ & $\begin{array}{l}49.2 \\
27.4 \\
19.5\end{array}$ & $\begin{array}{l}8 \\
7 \\
8\end{array}$ & $\begin{array}{r}.8 \\
1.2 \\
1.8\end{array}$ & $\begin{array}{l}3.3 \\
5.0 \\
7.5\end{array}$ & $\begin{array}{r}54 \\
84 \\
165\end{array}$ & $\begin{array}{l}4.9 \\
2.0 \\
4.4\end{array}$ & 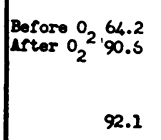 & i1 & $76-80$ & $\begin{array}{l}\text { Ischenic for } 80 \\
\text { nimutes prlor to } \\
\text { Injectice of } 1 e^{22} \text {. }\end{array}$ \\
\hline
\end{tabular}

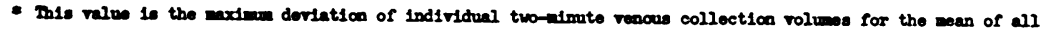
two-ainute collection rolumes for the entire clearance poriod, expressed in por cent.

this preparation the "recirculation" of radioactive sodium through the muscle was completely eliminated.

It was frequently noted during the later portions of an experiment that the clearance rate for any given blood flow would progressively decrease. When the same rate of blood flow was maintained for two or three clearance periods in the late phase of the experiments, progressive "flattening" 1 of the slope of disappearance of $\mathrm{Na}^{\text {" often }}$

1 The term "flattening" refers to a progressive decrease in the rate of clearance of radioactive sodium as a function of a given rate of flow. was observed. When this "flattening" phenomenon was observed, the results from these latter clearance periods were not included in the data in Table $I$.

No reinjections of radioactive sodium were performed in any of these experiments. It had previously been learned that a high rate of flow for a long time interval was usually required to completely remove all of the radioactive sodium from the muscle and thus obtain a count which was even near the original background count.

Collateral blood flow, which could have inadvertently 
resulted from failure to ligate small arterial branches and venous tributaries, was checked by placing a hemostat on the perfusion tube which was connected to the arterial cannula. Absence of venous outflow during this procedure was accepted as evidence of an isolated circulation to the biceps muscle. Either small arterial branches joining the brachial artery distal to the cannula or small venous tributaries joining the brachial vein proximal to the venous cannula would have resulted in a flow of blood from the venous cannula. If evidence for collateral vessels was found, and the vessels could not be obliterated, the experimental data were considered invalid and not reported.

At the termination of each experiment India Ink was injected into the arterial cannula. The ink flowed relatively easily through the muscle vasculature and drained from the venous cannula. No evident swelling of the muscle was produced by perfusion of either the blood or the colloidal suspension of India Ink. The biceps muscle was then removed and sectioned with a scalpel. In each experiment the muscle was found to be diffusely and homogeneously darkened. The muscle was then weighed. Section of neighboring muscles in the foreleg with a scalpel revealed no evidence of darkening with the colloidal suspension.

Experiment Nos. 1A, 2A, and 3A were performed in the usual way except that the muscle was purposely made anoxic and ischemic. After cannulation of the vessels, and prior to the onset of perfusion and injection of the radioactive sodium intramuscularly, the muscle was allowed to remain without any blood supply for a period of 75 to 80 minutes. Then the perfusion and injection of the $\mathrm{Na}^{23}$ were carried out in the usual way.

Experiment Nos. 1B, 2B, and 3B were performed to

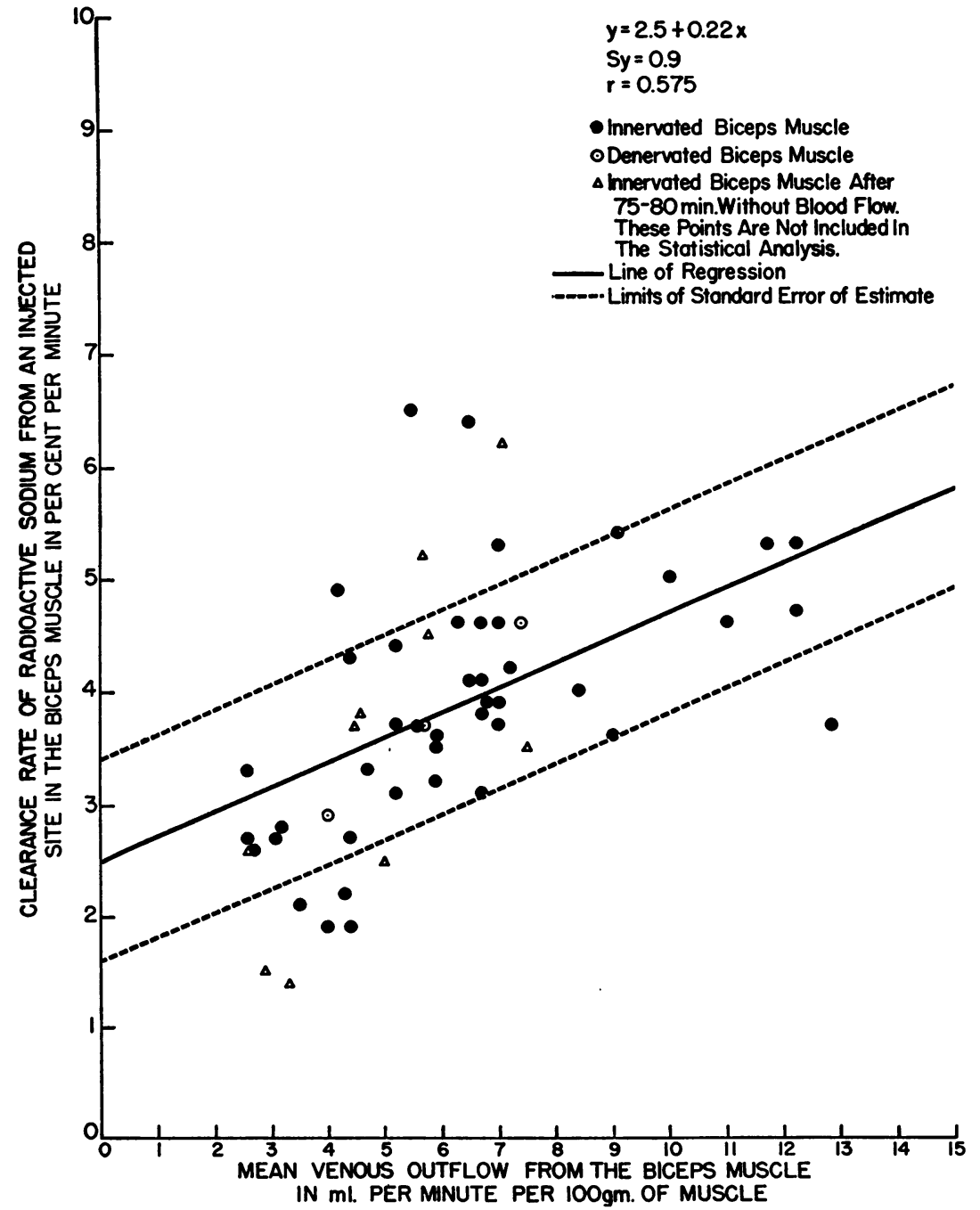

Fig. 3. Linear Relationship between Clearance of Radioactive Sodium from Injected Site in Muscle and Blood Flow through the Muscle

The wide variation in clearance rate for any given flow is evident. 
test the closeness of correlation between flow rate and clearance of $\mathrm{Na}^{2}$ from muscle following its injection into the arterial supply to that muscle. They differed from the other experiments in the following respects. Instead of injecting the radioactive sodium intramuscularly, $\mathrm{Na}^{2}$ (25 microcuries in $0.5 \mathrm{ml}$. in Experiment Nos. $1 \mathrm{~B}$ and 2B and 20 microcuries in $0.4 \mathrm{ml}$. in Experiment No. 3B) was injected into the perfusion tube just proximal to the intra-arterial cannula. In Experiment Nos. $1 B$ and 2B the clearance periods were much longer than in previous experiments. In Experiment No. 3B the clearance periods were of the usual length. At the termination of each of these experiments the biceps muscle was injected with India ink and then removed without changing the original position of the scintillation tube. In each instance the counts after removal of the muscle were very close to background and it was concluded that there was very little contamination of the tubing and cannulae distal to the injection site.

The oxygen saturation of the blood used for perfusion was determined by the method of Gordy and Drabkin (6).

The plasma hemoglobin concentration of the blood used for perfusion was determined by the method of Creditor (7).

\section{RESULTS}

Relationship between blood flow and clearance rate of radioactive sodium from an intramuscular injection site in muscle with an adequate supply of oxygenated blood

The over-all results of the correlation between the clearance rate of radioactive sodium from an injected site in the biceps muscle and the blood flow through the muscle can be seen in Table I and Figure 3. A linear relationship as determined statistically was noted between clearance and flow. However, the large standard error of estimate about the line of regression prevented accurate estimation of flow from a given clearance value.

The linearity of the line of regression was tested by the analysis of variance about the line using the method of Fisher (8). The deviations from linear regression were not significant-they were fully accounted for by the variations within the arrays; so linearity was indicated. The equation found for the line of regression was $y=2.5+$ $.22 \times$. The standard error of estimate about this line of regression was 0.9. Thus 99 per cent of the clearance values for a given flow would fall between plus or minus 2.7 per cent $(2.7$ per cent referring to units of the ordinate rather than per cent variation about the line). The coefficient of correlation was 0.57 . This can be considered a

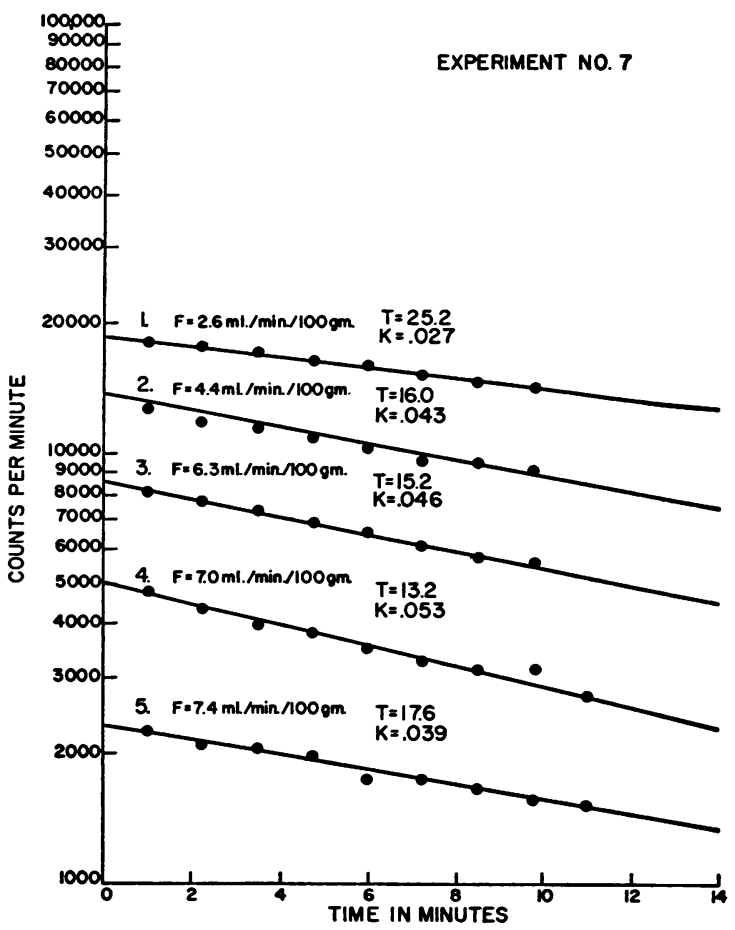

Fig. 4. Progressive Increase in Exponential Slopes of Disappearance of Na" from InJected Stre in Muscle as a Function of Increasing Perfusion RATES

Slope 5 illustrates the "flattening" effect seen in later phases of some experiments.

significant correlation since the value of " $z$ ", derived from the coefficient of correlation, exceeded three times the standard error of " $z$ ".

Figure 4 demonstrates typical slopes of disappearance of radioactive sodium from an injected site in the biceps muscle with increasing rates of perfusion during successive clearance periods. (Taken from Experiment No. 7.) It can be seen that clearance rate and blood flow rise concordantly during the first four clearance periods. However, progressive decrease in clearance rate, as a function of flow, was observed during the last two clearance periods even though the flow was maintained relatively constant. Data from the fifth and sixth clearance periods of this experiment were not included in the analysis of the results. Similar terminal clearance periods from those other experiments which demonstrated "flattening" were likewise not included.

To further clarify, in a quantitative way, the relationship between clearance rate of radioactive 
sodium from the muscle and perfusion rate the following calculations were made. The degree of increase or decrease in the values of clearance rate and blood flow between successive clearance periods in each experiment was calculated. These values were expressed as ratios of the clearance and flow, respectively, of each successive clearance period to its predecessor. The change in flow was then divided by the change in clearance for each interval between clearance periods, thus giving a quantitative estimate of the relationship between change in flow and change in clearance. The results of these computations are shown in Table II. In 50 per cent of the instances the degree of change in clearance and flow found between successive clearance periods were within plus or minus ten per cent of each other.

Progressive increase in the ratio between the change in flow and the change in clearance between successive clearance periods was accepted as evidence of "flattening." This trend was not evident in the data selected for analysis. In instances where it was noted, invariably in the later clearance periods of an experiment, these data were deleted.

The flow produced by the infusion pump was pulsatile in character having about 40 beats per minute. The pulse pressure varied between 8 and 18 millimeters of mercury, independent of the total pressure within the system.

There was no obvious relationship noted between the ambient temperature and the results of any of the experiments.

In view of the previous reports that elevated plasma hemoglobin produces vasodilatation, the hemoglobin concentration in the perfusating plasma was measured. No relationship was found between levels of plasma hemoglobin and the results of the experiments.

Relationship between blood flow and clearance rate of radioactive sodium from an intramuscular injection site in muscle following a 75 to 80minute period of ischemia and anoxia

The data from three experiments in which radioactive sodium was injected into an ischemic

TABLE II

Table of ratios indicating the quantitative changes in clearance rates $(C)$ and flow rates $(F)$ during successive clearance periods, and the relationship of change in flow rate to change in clearance rate

\begin{tabular}{|c|c|c|c|c|c|c|c|c|c|}
\hline $\begin{array}{c}\text { Number } \\
\text { of } \\
\text { experi- } \\
\text { ment }\end{array}$ & $\begin{array}{c}\text { Clearance } \\
\text { periods } \\
\text { determining } \\
\text { ratio }\end{array}$ & $\begin{array}{l}\text { Ratio } \\
\mathbf{C}_{2} / \mathbf{C}_{1}\end{array}$ & $\begin{array}{l}\text { Ratio } \\
\mathrm{F}_{2} / \mathrm{F}_{1}\end{array}$ & $\frac{F_{2}}{F_{1}} \div \frac{C_{2}}{C_{1}}$ & $\begin{array}{l}\text { Number } \\
\text { of } \\
\text { experi- } \\
\text { ment }\end{array}$ & $\begin{array}{c}\text { Clearance } \\
\text { periods } \\
\text { determining } \\
\text { ratio }\end{array}$ & $\begin{array}{l}\text { Ratio } \\
\mathbf{C}_{2} / \mathbf{C}_{1}\end{array}$ & $\begin{array}{l}\text { Ratio } \\
F_{3} / F_{1}\end{array}$ & $\frac{F_{2}}{F_{1}} \div \frac{C_{2}}{C_{1}}$ \\
\hline 1 & $\begin{array}{l}2 / 1 \\
3 / 2 \\
4 / 3 \\
5 / 4\end{array}$ & $\begin{array}{r}1.73 \\
.97 \\
1.27 \\
.66\end{array}$ & $\begin{array}{r}1.56 \\
1.91 \\
.95 \\
.55\end{array}$ & $\begin{array}{r}.90 \\
1.96 \\
.75 \\
.83\end{array}$ & 7 & $\begin{array}{l}2 / 1 \\
3 / 2 \\
4 / 3\end{array}$ & $\begin{array}{l}1.60 \\
1.07 \\
1.15\end{array}$ & $\begin{array}{l}1.69 \\
1.43 \\
1.11\end{array}$ & $\begin{array}{r}1.06 \\
1.34 \\
.96\end{array}$ \\
\hline 2 & $\begin{array}{l}2 / 1 \\
3 / 2\end{array}$ & $\begin{array}{l}1.27 \\
1.24\end{array}$ & $\begin{array}{l}1.42 \\
1.30\end{array}$ & $\begin{array}{l}1.12 \\
1.05\end{array}$ & 8 & $\begin{array}{l}2 / 1 \\
3 / 2 \\
4 / 3\end{array}$ & $\begin{array}{r}1.48 \\
1.33 \\
.98\end{array}$ & $\begin{array}{l}1.61 \\
1.31 \\
1.18\end{array}$ & $\begin{array}{l}1.09 \\
.98 \\
1.2\end{array}$ \\
\hline 3 & $\begin{array}{l}2 / 1 \\
3 / 2 \\
4 / 3\end{array}$ & $\begin{array}{r}1.27 \\
.97 \\
1.22\end{array}$ & $\begin{array}{l}1.74 \\
1.25 \\
1.19\end{array}$ & $\begin{array}{r}1.37 \\
1.28 \\
.97\end{array}$ & 9 & $\begin{array}{l}2 / 1 \\
3 / 2 \\
4 / 3\end{array}$ & $\begin{array}{l}1.48 \\
1.48 \\
1.17\end{array}$ & $\begin{array}{l}1.48 \\
1.35 \\
1.30\end{array}$ & $\begin{array}{l}1.0 \\
.91 \\
1.11\end{array}$ \\
\hline 4 & $\begin{array}{l}2 / 1 \\
3 / 2 \\
4 / 3\end{array}$ & $\begin{array}{r}.69 \\
1.37 \\
\\
2.16 \\
.88 \\
1.28\end{array}$ & $\begin{array}{l}.44 \\
2.26 \\
\\
1.62 \\
1.38 \\
1.22\end{array}$ & $\begin{array}{r}.75 \\
1.56 \\
.95\end{array}$ & 10 & $\begin{array}{l}2 / 1 \\
3 / 2 \\
4 / 3 \\
5 / 4 \\
6 / 5\end{array}$ & $\begin{array}{r}1.00 \\
1.24 \\
.76 \\
1.17 \\
.88\end{array}$ & $\begin{array}{r}.93 \\
1.29 \\
.88 \\
1.13 \\
.88\end{array}$ & $\begin{array}{r}.93 \\
1.04 \\
1.16 \\
.96 \\
1.00\end{array}$ \\
\hline 5 & $\begin{array}{l}2 / 1 \\
3 / 2 \\
4 / 3 \\
5 / 4\end{array}$ & $\begin{array}{r}1.57 \\
.89 \\
1.02 \\
.47\end{array}$ & $\begin{array}{r}1.62 \\
1.31 \\
1.23 \\
.52\end{array}$ & $\begin{array}{l}1.03 \\
1.47 \\
1.20 \\
1.11\end{array}$ & $1 \mathrm{~A}$ & $\begin{array}{l}\text { Ischem } \\
2 / 1 \\
3 / 2 \\
4 / 3\end{array}$ & $\begin{array}{l}\text { and An } \\
1.42 \\
1.22 \\
1.38\end{array}$ & $\begin{array}{r}\text { uscle } \\
1.73 \\
1.28 \\
1.22\end{array}$ & $\begin{array}{r}1.22 \\
1.05 \\
.88\end{array}$ \\
\hline 6 & $\begin{array}{l}2 / 1 \\
3 / 2 \\
4 / 3 \\
5 / 4\end{array}$ & $\begin{array}{l}1.55 \\
1.19 \\
1.06 \\
1.00\end{array}$ & $\begin{array}{l}1.64 \\
1.38 \\
1.17 \\
1.04\end{array}$ & $\begin{array}{l}1.06 \\
1.16 \\
1.10 \\
1.04\end{array}$ & $2 A$ & $\begin{array}{l}2 / 1 \\
3 / 2 \\
2 / 1 \\
3 / 2\end{array}$ & $\begin{array}{l}2.53 \\
1.37 \\
1.78 \\
1.40\end{array}$ & $\begin{array}{l}1.59 \\
1.24\end{array}$ & $\begin{array}{r}.63 \\
.91 \\
.85 \\
1.07\end{array}$ \\
\hline
\end{tabular}




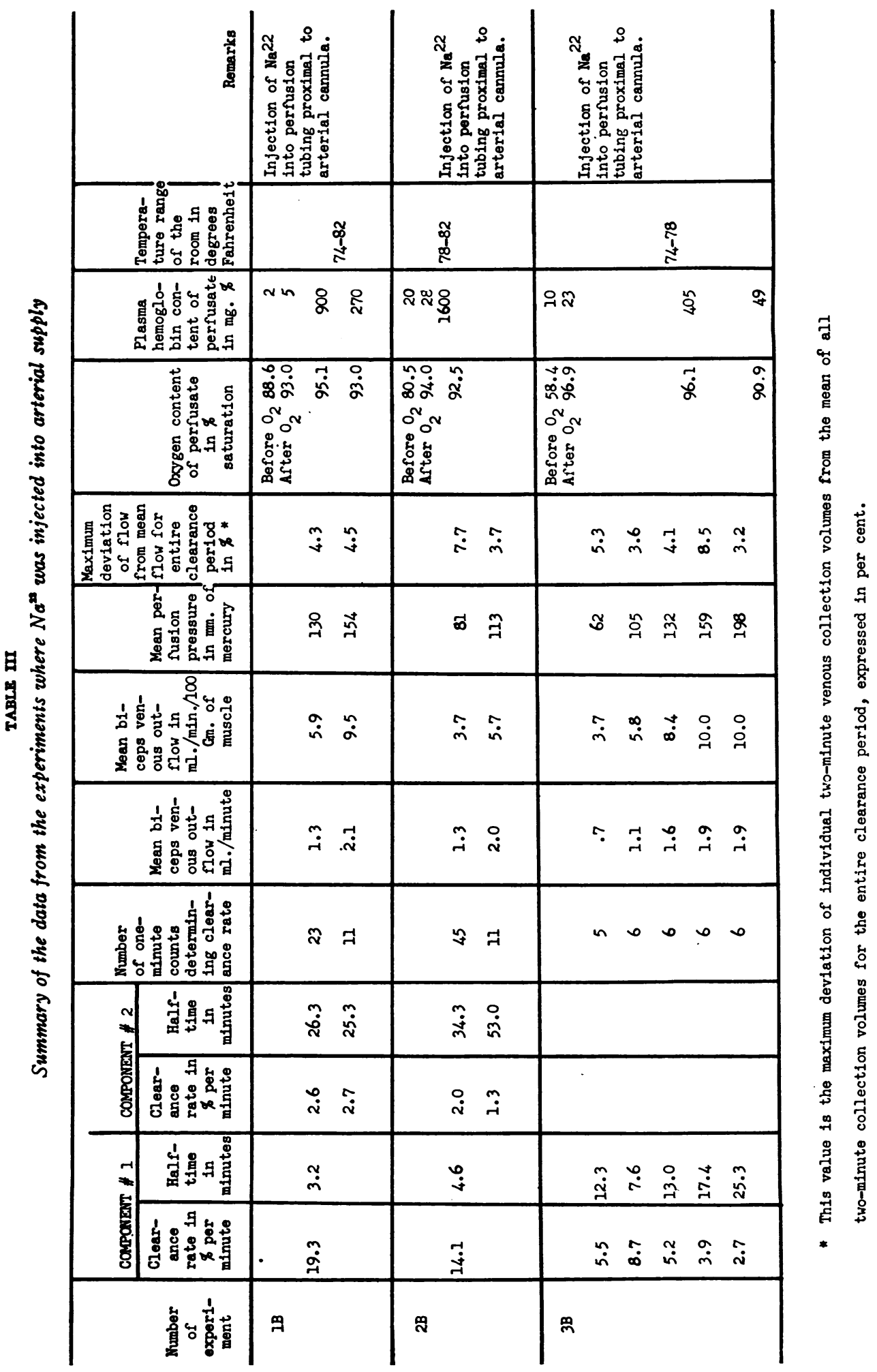




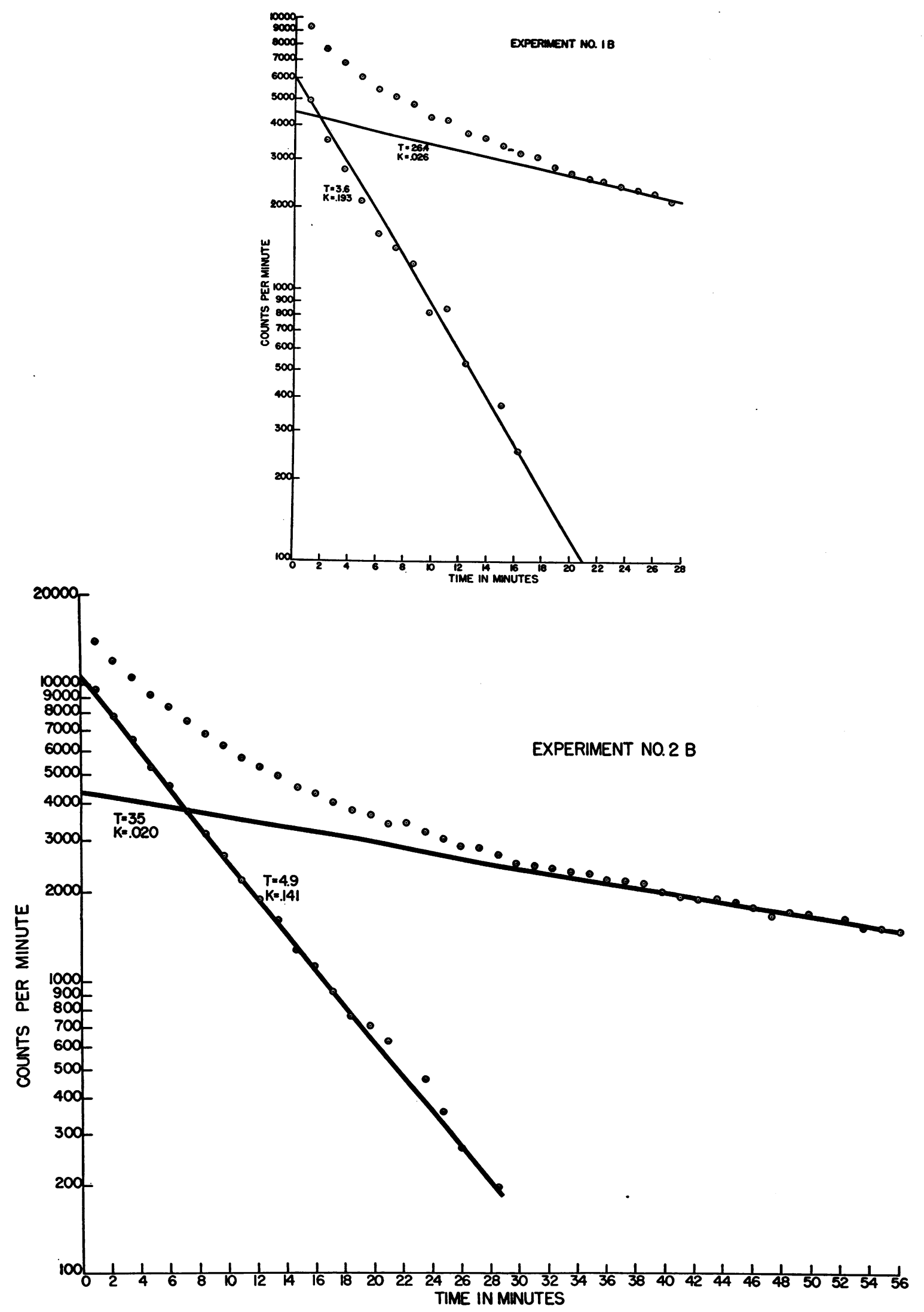

Figs. 5 and 6. Two Component Exponential Slope of Disappearance of Na" from Perfused Muscle after Its InJection into the Arterial Supply to the Muscle 
and anoxic muscle are recorded in the latter part of Table I. In each of these experiments the muscle was completely without blood flow for a period of 75 to 80 minutes. The relationship between clearance rate of radioactive sodium and rate of blood flow in this preparation, following this period of ischemia, was very similar to that found in the first ten experiments in which the muscle had an adequate supply of oxygenated blood (Figure 3 ). During the first clearance period of Experiment Nos. 2A and 3A, during which the rate of blood flow was low, the clearance rate of radioactive sodium was less than that seen in any oxygenated muscle for a similar range of blood flow. However, the subsequent clearance values for any given blood flow for these experiments, as well as all the clearance values in Experiment No. 1A, fell within the scatter of data for the first ten experiments. The data from these three experiments are not included in the statistical analysis of the data for the first ten experiments.

Relationship between blood flow and clearance rate of radioactive sodium from muscle following intra-arterial injection of $\mathrm{Na}^{22}$ into the nutrient artery supplying the muscle

Three experiments were performed in which the clearance rate of radioactive sodium from the biceps muscle was determined following the injection of $\mathrm{Na}^{22}$ into the perfusion tube immediately proximal to the arterial cannula (Table III). In two of these experiments (1B and $2 \mathrm{~B}$ ) an attempt was made to maintain the perfusion rate at a constant level until the clearance rate of $\mathrm{Na}^{22}$ from the muscle had reached a constant value. In Experiment No. 2B it was necessary after the first thirty minutes, during which time the flow was maintained constant at a level of $4.0 \mathrm{ml}$. per minute per $100 \mathrm{Gm}$. of muscle (maximum deviation 4.4 per cent) to refill the syringe on the pump. After this was accomplished the flow was maintained at a slightly lower level, $3.4 \mathrm{ml}$. per minute per $100 \mathrm{Gm}$. of muscle (maximum deviation 9.8 per cent). The values recorded for the first clearance period in the data in Table III are the average of these two values. The maximum deviation from mean two-minute flow was calculated using the mean of all two-minute collection volumes throughout the entire 53.5 minutes. In both experiments the disappearance rate of radioactive sodium from the muscle could be separated into two exponential components with widely variant rate constants. The results are illustrated in Figures 5 and 6 . In both of these experiments, when a constant rate of clearance appeared to have been reached, the perfusion rate was raised. In Experiment No. 1B the perfusion rate was raised from 5.9 to $9.5 \mathrm{ml}$. per min. per $100 \mathrm{Gm}$. and in Experiment No. 2B from 3.7 to $5.7 \mathrm{ml}$. per min. per $100 \mathrm{Gm}$. In neither instance was there any resultant increase in the clearance rate subsequent to the increase in perfusion rate. In $2 \mathrm{~B}$ the clearance rate during this period of increased flow actually decreased slightly. The values for the last clearance periods in $1 \mathrm{~B}$ and $2 \mathrm{~B}$ were recorded under "Component No. 2" in Table III since they differed little from the slower component.

In Experiment No. 3B perfusion was started at a low rate, $3.7 \mathrm{ml}$. per min. per $100 \mathrm{Gm}$., and was increased stepwise during four subsequent clearance periods to a maximum of $10 \mathrm{ml}$. per min. per $100 \mathrm{Gm}$. Table III shows the results. There was a rise in the clearance rate during the second clearance period as compared to the first, concomitant with the rise in perfusion rate. However, during successive clearance periods thereafter the clearance rates decreased progressively in spite of increasing perfusion rates. During the last two clearance periods a relatively constant perfusion rate of $10 \mathrm{ml}$. per min. per $100 \mathrm{Gm}$. was maintained and the clearance rates continued to decrease, going from 3.9 per cent in the fourth clearance period to 2.7 per cent in the last.

\section{DISCUSSION}

The results of the intramuscular injection experiments, namely, the wide range of blood flow represented by any given clearance rate of radioactive sodium, tend to minimize the value of this method as an index of total muscle blood flow.

There are several factors which may be responsible in greater or lesser degree for this lack of correlation between rate of clearance of radioactive sodium from an intramuscular injection site and total blood flow through the muscle. These can be divided conveniently into physiological factors and anatomical factors. 


\section{Physiological factors}

The presence of effective shunts at the arteriolar level which by-pass a fraction of the arterial blood around the capillary circulation could be important in producing the observed lack of correlation between total blood flow and radioactive sodium clearance. Since, presumably, radioactive sodium is cleared from the injected site only by blood flow at the capillary level, the radioactive sodium clearance would correlate only with that fraction of total blood flow not shunted. What quantitative significance shunts actually possess is not known at the present time and therefore their influence on the present data cannot be evaluated.

Pappenheimer, Renkin, and Borrero (9) have shown from their data on osmotic transients that at low blood flows the diffusion rate of sodium. chloride is flow limited. The question arises as to whether, at higher levels of blood flow, the exchange of sodium between the vascular system and extracellular space may be limited by permeability factors and the diffusion rate of sodium rather than by blood flow per se. Jones (10) presented evidence that the exchange rates in various tissues of several inert gases, having an eightfold range of relative diffusion rates, were approximately the same. These results led to the view that diffusion and transcapillaric permeability were not factors limiting the inert-gas-exchange rate and that in fact blood flow determined the exchange rate. The linearity of our clearance/flow relationship and the absence of any consistent reduction in increment of clearance rates at higher blood flows suggest that radioactive sodium exchange in these experiments was not limited at higher levels of blood flow by diffusion or permeability factors.

Although sodium is freely diffusible it is certainly not inert and consequently is subject to such influences as electric potential gradient and chemical combination. What effect these influences had on our results cannot be assessed.

It is now known that muscle fibers àre not impermeable to sodium and hence that an energyusing transport system must be operative to drive outward the sodium that enters by diffusion and thus to keep it in its primarily extracellular location $(11,12)$. That this "sodium pump" may have been injured via anoxia and other factors during the dissection was a possibility. How such injury would effect our clearance values was not known. However, it was suspected that by allowing a portion of radioactive sodium to diffuse into the muscle fibers the amount available for clearance might have been decreased. The three anoxic experiments were carried out to measure the effects of complete absence of blood supply over a 75 to 80-minute interval on the clearance of radioactive sodium. The data from these experiments did not indicate any obvious effect of anoxia on the clearance rate of radioactive sodium as a function of flow. In light of these findings, as well as the fact that we were perfusing with relatively well-oxygenated blood, it would appear that anoxia was not a significant contributing factor to the wide scatter of data.

\section{Anatomical factors}

The anatomical factors which could possibly affect the correlation between clearance rate and flow have been discussed by others. They involve principally the vascularity of the site selected for injection, the degree of tissue injury produced by the injection, and the amount of distortion and compression of local tissues produced by the injected fluid. It has been shown recently (13) that the clearance rate is dependent upon the volume of fluid injected into the muscle; larger volumes result in lower clearances. The present studies shed no further light on this general aspect of the problem but it seems likely that these local anatomical factors may be of importance in producing some of the discrepancies in correlation.

The clearance rate following intra-arterial injection of radioactive sodium was measured in three experiments to observe its correlation with blood flow. By injecting radioactive sodium ion into an artery, a large portion of the injected material can be localized in the region supplied by the vessel due to the rapid exchange which occurs with the local sodium pool. The subsequent rate of removal (clearance) of this residual material can then be measured. Dobson, Warner, Pace, Finney, and Johnston (14) reported the original studies using this method and found that "the rate of removal is not constant and is much more rapid than it is in the case of local injections. The variation of the removal rate with time can 
be explained on the basis of differing degrees of vascularity in the tissue."

If the diffusion rate of sodium is very rapid over such tissue and cell barriers as may exist, compared to the rate of movement of blood through the capillaries, then the clearance rates following intra-arterial injection should reflect vascularity of tissue. The quantitative aspects of blood flow as determined by clearance rates of intra-arterially injected $\mathrm{Na}^{22}$ could be handled analogously to the methods of Jones (10) using inert gases except for two correction factors to allow for 1) the differing concentration of sodium between blood and tissue and 2) the fact that sodium is limited to the sodium space. The above interpretation would lead one to believe that in Experiments $1 \mathrm{~B}$ and 2B there were two differently vascularized areas of tissue within the muscle; the one with a high time constant having a relatively high rate of flow and the one with a low time constant having a relatively low rate of flow for a given total blood flow to the muscle. One would have expected, however, that in Experiments $1 \mathrm{~B}$ and $2 \mathrm{~B}$ an increase in the remaining slow component should have occurred subsequent to an increase in total blood flow. That this did not occur would tend to invalidate the conclusion that the clearance rates of sodium from muscle following intra-arterial injection were dependent only upon blood flow to the part.

In Experiment 3B, except for the second clearance period, the clearance rates decreased progressively in spite of increasing blood flow. Interpretation here is more difficult. These results could occur 1) because clearance rate was dependent upon other factors as well as blood flow, and 2) that during clearance periods 1 and 2 most of the radioactive sodium was removed from the more highly vascularized area and subsequent decreases in clearance were accounted for by increasing predominance of clearance from the less vascularized area.

\section{SUMMARY AND CONCLUSIONS}

Ten experiments were performed to establish the correlation between the clearance rate of radioactive sodium from an intramuscular injection site and total blood flow through the biceps muscle of the dog. A linear relationship was found to exist between these two variables. However, the scatter of data around the line of regression was so great that the clearance rate of radioactive sodium could not be utilized as an accurate measure of total blood flow.

Three similar experiments were performed after a 75 to 80-minute interval during which time the biceps muscle was completely deprived of blood supply. Comparison of results from these three experiments with those of the previous ten revealed no obvious difference in the relationship between clearance and flow. These results, coupled with the fact that the muscle was perfused with relatively well oxygenated blood, were considered as evidence that anoxia was not a significant contributing factor to the wide scatter of the data in the first ten experiments.

Three experiments were performed in an attempt to establish the correlation between the clearance rate of radioactive sodium from muscle, subsequent to its intra-arterial injection, and blood flow through the muscle. The data from these experiments did not support the concept that the clearance rate of radioactive sodium under these circumstances was solely dependent upon blood flow.

\section{ACKNOWLEDGMENTS}

We are grateful to many for their help and advice. We wish to express our sincere appreciation and thanks to Dr. Robert W. Clarke, Chief of Department of Surgical Physiology, Army Medical Service Graduate School, Walter Reed Army Medical Center, for his guidance and interest in our project; to Dr. Lewis Sokoloff, $\mathrm{Na}$ tional Institutes of Health, for his suggestions regarding the experimental preparation; to Dr. Audie Lubin, Department of Psychology, Walter Reed Army Medica! Center, for his help with the statistical analysis of the data; and to Mrs. Ann Marsh and Sgt. Willard R. Gauthier for their technical assistance.

\section{REFERENCES}

1. Kety, S. S., Measurement of regional circulation by the local clearance of radioactive sodium. Am. Heart J., 1949, 38, 321.

2. Wisham, L. H., Yalow, R. S., and Freund, A. J., Consistency of clearance of radioactive sodium from human muscle. Am. Heart J., 1951, 41, 810.

3. McGirr, E. M., The rate of removal of radioactive sodium following its injection into muscle and skin. Clin. Sc., 1952, 11, 91.

4. Miller, H., and Wilson, G. M., The measurement of blood flow by the local clearance of radioactive sodium. Brit. Heart J., 1951, 13, 227. 
5. Semple, R., McDonald, L., and Ekins, R. P., Radioactive sodium $\left(\mathrm{Na}^{24}\right)$ in the measurement of local blood flow. Am. Heart J., 1951, 41, 803.

6. Gordy, E., and Drabkin, D. L., A simplified spectrophotometric technique applicable to standard equipment for the determination of $\mathrm{O}_{2}$ saturation of blood. Am. J. M. Sc., 1951, 221, 231.

7. Creditor, M. C., The quantitative determination of plasma hemoglobin by the benzidine reaction. J. Lab. \& Clin. Med., 1953, 41, 307.

8. Fisher, R. A., Statistical Methods for Research Workers, 11th ed., Edinburgh, Oliver and Boyd, 1950.

9. Pappenheimer, J. R., Renkin, E. M., and Borrero, L. M., Filtration, diffusion and molecular sieving through peripheral capillary membranes: A contribution to the pore theory of capillary permeability. Am. J. Physiol., 1951, 167, 13.
10. Jones, H. B., Respiratory system: Nitrogen elimination in Medical Physics, Vol. 2, Otto Glasser, Ed., Chicago, Yearbook Publishers, Inc., 1950, p. 855.

11. Ussing, H. H., Transport of ions across cellular membranes. Physiol. Rev., 1949, 29, 127.

12. Steinbach, H. B., Sodium extrusion from isolated frog muscle. Am. J. Physiol., 1951, 167, 284.

13. Warner, G. F., Dobson, E. L., Pace, N., Johnston, M. E., and Finney, C. R., Studies of human peripheral blood flow: The effect of injection volume on the intramuscular radiosodium clearance rate. Circulation, 1953, 8, 732.

14. Dobson, E. L., Warner, G. F., Pace, N., Finney, C. R., and Johnston, M. E., Clearance rates following intra-arterial injection of radioactive sodium as a measure of regional blood flow. Federation Proc., 1953, 12, 33. 